\title{
West Java Community Motives for Exercising: APMO Analysis of West Java Province 2019
}

\author{
Dicky Waluya Badrukamal*, Adang Suherman, Amung Ma'mun \\ Sports Education Study Program, School of Postgraduate Studies, Universitas Pendidikan Indonesia, Bandung, Indonesia
}

Received April 23, 2021; Revised July 12, 2021; Accepted July 23, 2021

\section{Cite This Paper in the following Citation Styles}

(a): [1] Dicky Waluya Badrukamal, Adang Suherman, Amung Ma'mun, "West Java Community Motives for Exercising: APMO Analysis of West Java Province 2019," International Journal of Human Movement and Sports Sciences, Vol. 9 , No. 4A, pp. 136 - 142, 2021. DOI: 10.13189/saj.2021.091323.

(b): Dicky Waluya Badrukamal, Adang Suherman, Amung Ma'mun (2021). West Java Community Motives for Exercising: APMO Analysis of West Java Province 2019. International Journal of Human Movement and Sports Sciences, 9(4A), 136 - 142. DOI: 10.13189/saj.2021.091323.

Copyright $C 2021$ by authors, all rights reserved. Authors agree that this article remains permanently open access under the terms of the Creative Commons Attribution License 4.0 International License

\begin{abstract}
One of the determinant aspects of the success of sports development in one area is the level of the Community Participation Rate in Sports (APMO). This study presented the results of West Java Community Participation Rate in Sports (APMO) in 2019 and also revealed the motives (goals and methods) of the community in exercising, which was a part of the activity tracking of the Sports Community Participation Rate in West Java. Cross Sectional Study was used to uncover research problems, involving 108 staff of Bachelors of Sport Development Trainer (SP3OR) in the data collection process. The instrument used was a modified IPAQ questionnaire contained in the APMO Measurement Guidelines for the Youth and Sports Agency in 2017. The results of APMO measurements showed that $51.6 \%$ of West Java people were active in sports. $78.65 \%$ of them aimed to maintain health; $9.45 \%$ aimed to excel in sports; $4.4 \%$ aimed to lose weight; $4.38 \%$ aimed to increase association; $1.7 \%$ aimed to other purposes; $0.53 \%$ aimed to fill spare time; and $1.35 \%$ did not answer the question. $49 \%$ did sports independently; $20.2 \%$ participated in community/sports clubs; $15.3 \%$ participated in the school activities; $10.1 \%$ exercised at work; $3.98 \%$ did sport through other means, and $1.4 \%$ did not answer the question. The results of the study reveal that the majority of West Java people expect health benefits from sports activities carried out both independently and in community/sports clubs.
\end{abstract}

Keywords West Java APMO, Dispora, Sport Participation, SP3OR

\section{Introduction}

Sedentary behaviour, such as watching television, sitting all day in front of a computer, driving a private vehicle that takes more than 4 hours, is increasing (1) in big cities, such as Los Angeles and New South Wales, Australia. It is said that sedentary behaviour contributes to the increase of obesity in adults (2). In fact, the computer and internet users in households have increased from 15\% to $69 \%$ in the 1989 to 2009 period (1), so that sedentary behaviour becomes a problem for individual health.

Impaired health in individuals, as a result of continuous high level sedentary behaviour (such as sitting for long periods), is associated with abnormal glucose metabolism and cardiometabolic morbidity, as well as overall mortality (3). In fact, according to research, the number of people with level 2 diabetes in the world is estimated to increase from 240 million people in 2007 to 340 million people in 2025 and $60 \%$ of them come from Asia (4). This is a real threat to young generations around the world, including in West Java Province.

West Java is demographically the province with the largest population in Indonesia, with a projected population in 2020 was around 49.9 million people (5) or $18.4 \%$ of the total population in Indonesia. This is a long-term advantage, but at the same time, it will be a threat if this demographic excess is not managed seriously. Hence, the planning should be arranged as carefully as possible. The most 
obvious threat from the demographic bonus of West Java province is the increase in sufferers of degenerative non-communicable diseases, such as obesity, diabetes, coronary heart disease, and cancer (6) in the younger generation.

The increasing number of non-communicable diseases is indicated as one of the main causes of premature death (7). In this case, the West Java Provincial Government pays special attention to non-communicable diseases in the medium-term development plan (8), preventive and curative measures are continuously implemented to reduce the spread of non-communicable diseases to the younger generation in West Java. Preventive and curative measures continue to be implemented to reduce the spread of non-communicable diseases to the younger generation in West Java. One of the preventive steps being implemented is to invite West Java people to actively participate in sports. Sport and participation in sports have become an important welfare policy issue and are considered as solutions to many 'problems' faced by society (9). According to research, it is stated that preventive steps in preventing the risk of non-communicable diseases, such as cardiovascular disease, type- 2 diabetes, obesity, and several types of cancer, is exercising (1) with moderate physical activity for 30 minutes at least 4 times per week (10). Even, participation in sports in childhood and adolescence has been reported to increase the likelihood of high levels of physical activity later in life (11).

The implementation of activities carried out every year, of course, requires a measuring tool to see the increase occurred after sports activities were rolled out in West Java society. Therefore, the West Java Youth and Sports Service (DISPORA) prepares a strategic plan for the next 5 years since 2018, so that the participation of the West Java people continues to increase (12), and has also compiled the Guidelines for Measuring the Participation Rate of the West Java Community in Exercising (APMO), a modified IPAQ questionnaire as a data collection instrument used to see an increase in community sport participation in West Java.

The purpose of this study was to obtain data on the participation of the West Java people in exercising in the past week when filling out the questionnaire, as well as the motivation and how people in West Java exercised. We only dig up information on the quantity of exercise of the respondents, not on the quality of the activities they did. Therefore, to complete the data we got, it is necessary to conduct further research on the quality of sport activity movement carried out by West Java people.

\section{Materials and Methods}

This research was conducted using a cross sectional study method. The data collectors were 108 Bachelor of Sport Development Activators (SP3OR) from West Java
Provincial Youth and Sports Office assigned according to their home district. Therefore, the sampling mechanism was determined purposely, where samples were obtained by SP3OR staff. The samples were selected based on the presence of SP3OR personnel from 108 sub-districts representing each district/city in West Java. Data collection was carried out every three months in 2019. The average number of respondents who participated in filling out the questionnaire was 18,459 people from 108 sub-districts in 27 regencies/cities in West Java. The instrument used was the International Physical Activity Questionnaire (IPAQ) which was modified as stated in the guidebook for measuring the level of participation of the West Java community in sports (APMO) West Java Provincial Youth and Sports Office 2017.

\section{APMO Data Collection Procedure}

Samples were taken from 108 sub-districts in West Java as the work area of West Java SP3OR workers as data collectors. Then, SP3OR workers searched for information about the community in the place where data were taken based on six occupational strata, including professional and educational backgrounds, consisting of students, PNS (Civil Servants)/TNI (Indonesian Army) /POLRI (Indonesian National Police)/BUMN (State-Owned Enterprises), private employees, entrepreneurs, farmers/fishers, and others. Then, SP3OR workers determined individual samples from each stratum through purposive sampling, which was based on the affordability and effectiveness of data collection. Samples taken from each stratum were $10 \%$ of the population, but not less than 5 people (unless the population was less than 5 people) and a maximum of 30 people (although $10 \%$ of the population was more than 30 people). The sample was at least 7 years old. Sample selection was based on domicile of residence, not domicile of place of work.

\section{Instrument}

The instrument used in this study was a questionnaire consisting of 14 questions (as shown in the Appendix), where the focus of the questionnaire was to reveal the number of people's participation in sports, but at the same time, it was used to reveal indicators of the level of physical activity. At this level, the measured target was not solely the quality of participation, but the quantity of doing sport activities as indicated by the frequency of doing sports activities per week. In addition, respondents must also provide information about their height, weight, gender, age, and origin of the sub-district and district/city as well as occupational stratification.

\section{Results}

The results of the West Java APMO obtained from the 
respondent answers were 18,459 people, stating that 9,531 or $51.6 \%$ exercised in the last one week while the rest answered no.

\section{APMO Data Analysis}

The West Java APMO value is based on the "yes" answers of respondents to question number 1, namely "Have you done sports activities in the past week?". To get the APMO value per sub-district, the number of "yes" answers from each respondent were calculated using the formula:

$\mathrm{APMO}=\frac{\sum X 1}{n} \times 100 \%$

$\sum \mathrm{x} 1=$ Respondents who exercised/answered Yes

$\mathrm{n}=$ Total Respondents who filled out the Questionnaire

Furthermore, to get the APMO value per Regency/City, the average value in the sub-district was calculated. To get the APMO value at the Provincial level, the average score of the Regency/City was calculated.

The motivation and how the West Java people generally exercise can be seen from the results of the respondent answers to question number 9, namely "What is your main goal of exercising?", and question number 10 , namely " How do you exercise?". The percentage of results were obtained by looking at the average answers given by respondents to the questions mentioned above.

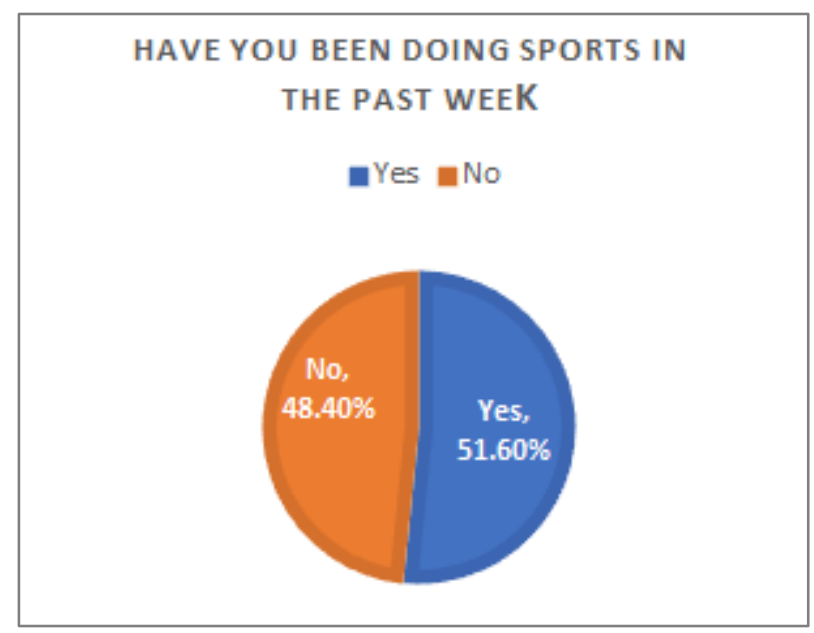

Figure 1. The participation of west java people in sports in 2019

With these results, of course, it was necessary to explore further the information behind the results obtained. In the questionnaire, there are also questions that explore information about the motivation listed in question number 9, "What is your main goal of exercising". The results of the respondent answers show that $78.65 \%$ aimed to maintain health, $9.45 \%$ aimed to perform well in sports, $4.4 \%$ aimed to lose weight, $4.38 \%$ aimed to increase socialization, $1.7 \%$ were for other purposes, $0.53 \%$ aimed to fill leisure time, and $1.35 \%$ did not answer.

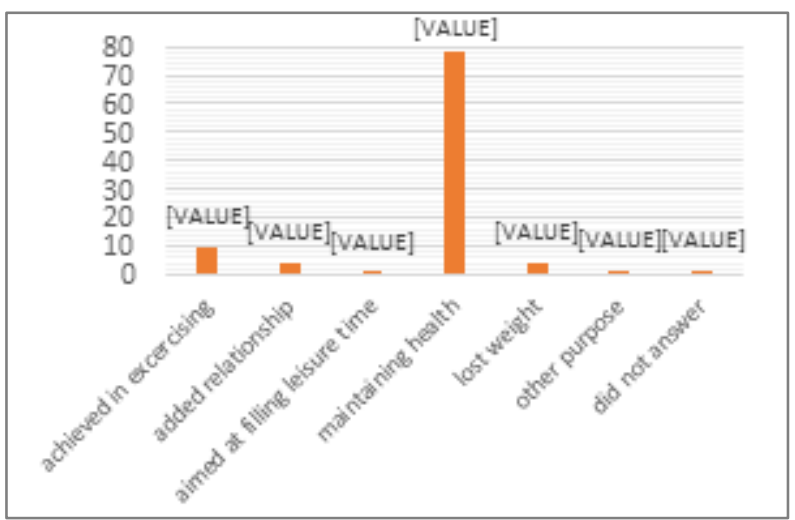

Figure 2. Exercise goals

To know how the respondent exercised, the question number 10, "How do you exercise?" was given. The results show that $49 \%$ of respondents did sports independently; $20.2 \%$ of respondents participated in community/sport clubs; $15.3 \%$ of respondents exercised at school; $10.1 \%$ exercised at work; and 3.98\% did sports through other means, and $1.4 \%$ did not answer.

\section{Discussions}

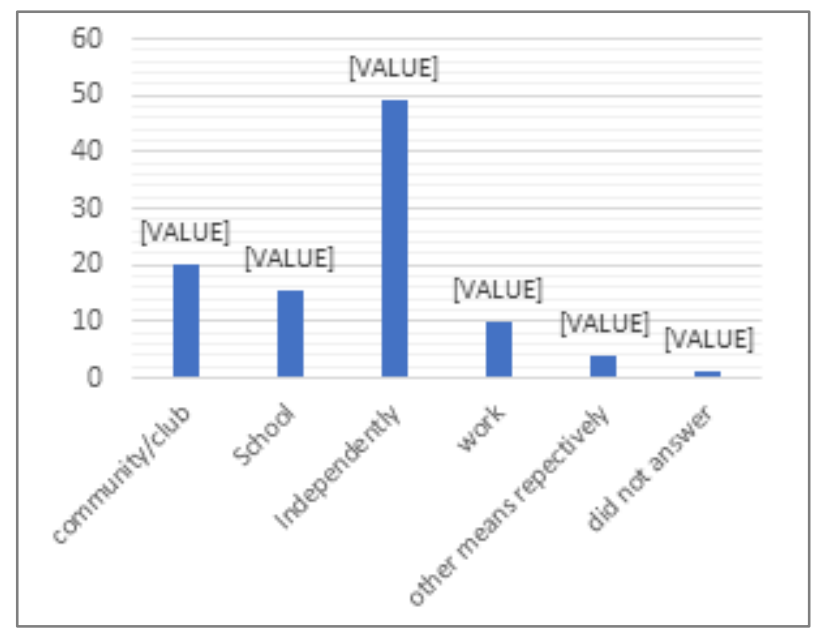

Figure 3. How the respondents exercised

\section{Discussion}

Motivation is a hypothetical construct used to describe the internal and/or external forces that lead to the initiation, direction, intensity, and persistence of behaviour (7). At least, four concepts are needed to analyse the processes that involve people in sports, namely recruitment, motivation, outreach, and commitment (13). Based on the results obtained from the measurement of the Public Participation Rate in Exercising (APMO), it was found that the majority of respondents answered that maintaining health was the main motivation for exercising. $78.65 \%$ answered that their exercising goal was to maintain health. It explains that the 
respondents had realized the importance of maintaining personal health and exercising was the most accessible preventive step for them to reach and implement.

Physical inactivity has an impact on the arrival of various diseases, while sport participation contributes to health and physical activity (Molenberg). Health is an indicator of one's happiness, because being able to live daily life with a maintained health for a long time is a great satisfaction, which is not owned by someone who is sick. Therefore, it is possible that the results of data collection on sport activities show that $51.6 \%$ of people did sports activities because the respondents had a strong intrinsic motive to obtain benefit from the activities carried out. In SDT, it explains vitality, the energy available for oneself, namely energy that is uplifting and empowering (14), in accordance with the objectives of sports activities.

Furthermore, in second place, $9.45 \%$ of respondents answered that their exercising goal was an achievement. It cannot be denied that currently life as an athlete is promising, because it can change the status and economy, especially in West Java. Therefore, it is true that when someone is extrinsically motivated, the individual does not engage in activities because of pleasure but to get a kind of reward outside the activity itself (13). The rest of the respondents answered that $4.4 \%$ for weight loss, $4.38 \%$ added relationships, $1.7 \%$ for other purposes, $0.53 \%$ filled the leisure time, and $1.35 \%$ did not answer.

The next data is how the respondents carried out sports. The data strengthens the statement that the respondent motivation was to maintain their health, where the majority of respondents answered that they exercised independently. Interesting facts were obtained from the answers. Respondents who answered that they did sports independently had a percentage of $49 \%$, while $20.2 \%$ of respondents answered that they participated in sport communities/clubs. From the two majority answers obtained, there is a correlation between the objectives and the way the respondents exercise. Therefore, it proves that the respondents have strong intrinsic and extrinsic motivation to achieve goals/satisfaction from their participation in sports [7] namely health and sports achievement.

\section{Conclusion}

The results of the Sports Community Participation Rate (APMO) in 2019 reached $51.6 \%$. This is a good result for the measure of sports development in the region. However, because the determination of the sample used purposive sampling and was only carried out in 108 sub-districts, or only $17.28 \%$ of the total 625 sub-districts, it would be better if the measurement is conducted in all sub-districts in West Java. Therefore, further research needs to involve samples that represent every District in West Java to gain better results.

Hopefully, a healthy lifestyle through refractive exercise will continue as well as efforts to globally promote recreational sports as a way of life (15). Indirectly, the results of the West Java APMO are also directly proportional to the achievements of West Java Province in national sports events, such as the POPNAS champion 3 times in a row $(2015,2017,2019), 2016$ PON Champion, 2016 PEPARNAS champion, and the province with the largest athletes contributor. At the 2018 Asian Games, 30\% of all athletes represented nationally.

\section{Acknowledgement}

The authors would like to thank Universitas Pendidikan Indonesia and Dinas Pemuda dan Olahraga Jawa Barat for their help and provision of infrastructure in this research. The study did not receive any financial support.

\section{Disclosure Statement}

No author has any financial interest or received any financial benefit from this research.

\section{Conflict of Interest}

The authors state no conflict of interest. 


\section{APPENDIX}

\section{Questionnaire}

Filled in by APMO Respondents

\section{INSTRUCTIONS}

Fill in the dots or put a cross (X) on the answer choices that suit you. Your answer is not judged right or wrong, which is important in accordance with actual conditions.

\section{IDENTITY}

Name:

Age:

Gender: (1) Male

(2) Female

Height:

Meters

Weight:

$\mathrm{Kg}$

Address:

Districs:

City:

Job:

Student

PNS/TNI/POLRI/BUMN

Private employees

Self-employed

Farmer/fisherman

Others

\section{Questions}

- Have you been doing sports in the past week?
1) Yes
2) No

If you answered Yes, go to number 2

If you answered No, continue to number 11

- How many times have you exercised vigorously, such as aerobic exercise, fast cycling, etc., that made you gasping for breath in the last week?
1) Once
2) Twice
3) Three Times
4) more than three times

- How much time do you spend on vigorous exercise?

....... Hour; minute

Don't know / not sure

- How many times have you had moderate exercise, such as swimming, cycling, etc. (not including walking), that made your breath a little out of breath in the past week?
1) Once
2) Twice
3) Three Times
4) more than three times 
- How much time do you spend on moderate exercise?

Hour; minute

Don't know / not sure

- How many times have you walked in the past week?
1) Once
2) Twice
3) Three Times
4) more than three times

- How much time do you spend walking?

Hour; minute

Don't know / not sure

- In exercising, what type of sport do you often do?
1) Football
2) Volley Ball
3) Badminton
4) Aerobic
5) Cycling
6) Basket Ball
7) Swimming
8) Self-Defense
9) Walking
10) Jogging/Running
11) Futsal
12) Other

- What is your main goal of exercising?
1) Maintaining Health
2) Losing weight
3) adding association
4) excelling in sports
5) other

- How do you exercise?
1) School
2) Club
3) Workplace
4) Independently
5) Others

- Have you ever felt lazy to do sports?

$\begin{array}{ll}\text { 1) Ever } & \text { 2) Never }\end{array}$ If you answered yes, proceed to number 12

- In the last 7 days, how long have you been sitting in one day?

....... Hour; minute

Don't know / not sure

- Why don't you do sports?
1) not interested
2) Don't Have Time
3) no facilities / infrastructure
4) tired
5) the work that I do is enough
6) Other

- In your opinion, how are the sports facilities in your area today?
1) adequate
2) inadequate
3) very inadequate 


\section{REFERENCES}

[1] P Owen N, Sparling PB, Healy GN, Dunstan DW, Matthews CE. Sedentary behavior: Emerging evidence for a new health risk. Mayo Clin Proc. 2010;85(12):1138-41.

[2] Pate RR, O’Neill JR, Lobelo F. The evolving definition of "sedentary." Exercise and Sport Sciences Reviews. 2008.

[3] WHO. Global Action Plan on Physical Activity 2018-2030. Journal of Policy Modeling. 2018.

[4] Chan JCN, Malik V, Jia W, Kadowaki T, Yajnik CS, Yoon $\mathrm{KH}$, et al. Diabetes in Asia: epidemiology, risk factors, and pathophysiology. JAMA - Journal of the American Medical Association. 2009.

[5] Badan Pusat Statistik. Proyeksi Penduduk menurut Provinsi, 2010-2035. 2014; 2035:1. Available from: https://www.bps.go.id/linkTabelStatis/view/id/1274

[6] Lower LM, Turner BA, Petersen JC. A Comparative Analysis of Perceived Benefits of Participation Between Recreational Sport Programs. 2013;66-83.

[7] Green BC. Building sport programs to optimize athlete recruitment, retention, and transition: Toward a normative theory of sport development. J Sport Manag.
2005;19(3):233-53.

[8] Pemerintah Daerah Provinsi Jawa Barat. Rancangan Rencana Pembangunan Jangka Menengah Daerah (RPJMD) Provinsi Jawa Barat 2018-2023. 2019;VI-31. Available from: http://bappeda.jabarprov.go.id/wp-content/uploads/2019/0 2/RPJMD-JABAR-2018-2023-BUKU-SATU-VERSI-4-F EB-2019.pdf

[9] Österlind M. Sport policy evaluation and governing participation in sport: governmental problematics of democracy and health. 2016; 6940(March).

[10] Brown WJ, Burton NW, Rowan PJ. Updating the Evidence on Physical Activity and Health in Women. Am J Prev Med. 2007;33(5).

[11] Tammelin T, Näyhä S, Hills AP, Järvelin MR. Adolescent participation in sports and adult physical activity. Am J Prev Med. 2003;24(1):22-8. renstra Dispora 2018-2023.pdf.

[12] Vallerand RJ. Intrinsic and Extrinsic Motivation in Sport. Encycl Appl Psychol Three-Volume Set. 2004;2:427-35.

[13] Deci EL, Ryan RM. Self-determination theory: A macrotheory of human motivation, development, and health. Can Psychol. 2008;49(3):182-5.

[14] Alexandris K, Carroll B. Motives for Recreational Sport Participation in Greece: Implications for Planning and Provision of Sport Services. 1997;3(2):129-43. 